\title{
Constructing the Identity of Modern Baba Nyonya
}

\section{Jiarong Liu}

School of South Asian and Southeast Asian Language and Cultures,

Yunnan Minzu University

Abstract: Baba Nyonya can be traced back to about 600 years ago when the very first batch of Chinese emigrated from China to Malacca, Singapore, Penang and Java of Indonesia.It was partially assimilated into the Malay culture, especially in food, dress and language used, while retaining some of the Chinese traditions and culture. Baba Nyonya represent special part of southeast Asian culture. This paper intent to reveal how the identity of modern Baba and Nyonya is constructed and evolved from time to time, the factors that lead to disappearance of the culture, and the future of the Baba Nyonya identity.Most importantly,how the community of Baba Nyonya and Malaysia society did to protect and carry on their identity and culture. To conclude, the identity of Modern Baba Nyonya is not disappearing but evolving into another stage with further mixture of other cultures. It has not been forgotten but has transformed into the new phrase of identity.

Keyword: Constructing, Baba Nyonya, identity

\section{Introduction}

This paper aims to investigate the identity of Baba Nyonya who lives in Malaysia, thus to study their origin, culture, current status and future prospect. The analysis will look in-depth into how the Baba Nyonya identity was constructed, and then evolve from time to time, the factor that leads to disappearance of the culture, and the future of the Baba Nyonya identity.

Identity is the defining character or personality of an individual as recognized by society. Identity is shaped as a result of a collaboration of social and personal experiences a person endures during the course of their life. The complex, multifaceted state of identity continuously makes it a component of human experience of great interest. In the different explorations of 'identity' demonstrate how difficult a concept it is to pin down. Since identity is a virtual thing, it is impossible to define it empirically. Discussions of identity use the term with different meanings, from fundamental and abiding sameness, to fluidity, contingency, negotiated and so on. (Brubaker \& Cooper 2000, p. 5)

The reason of choosing Baba Nyonya as research topic is because it is a typical example of mix marriage, and a unique form of independent identity and culture, however it's nearly disappearing.

\section{Research Methodology}

There are limitations conducting research on Peranakan culture. First of all, it is hardly to find Baba Nyonya nowadays. As the Peranakan culture is disappearing and therefore it is difficult to conduct the research. Snow ball technique has been applied in order to get more respondents for the survey. Museums and heritage sites are the best place where to trace back the culture. On the other hand, a few papers and journals have rise up this issue and elaborate about them in detail. In depth research has been done in some of the papers and journal. Primary research methods are also applied. For the attempt to further understanding the original identity of Baba Nyonya, the author went down to 
Malacca, where is the origin of Baba Nyonya for a site visit to witness the historical heritage. Through the site visit, the original tangible culture of Baba Nyonya such as the architecture, costume, food are observed. The most challenging part to examine the original Baba Nyonya culture is the intangible culture such as the belief, norms, language and etc. has been solved by secondary data. Besides, face-to-face interview and distributed questionnaire are conducted. As mentioned earlier, it is difficult to recognize Baba Nyonya in both Malacca and Kuala Lumpur nowadays as most of them look similar to either Chinese or Malay. Therefore, the snow ball technique is applied where one respondent lead to his or her acquaintance who is also a baba or nyonya. Face to face interview and questionnaires were distributed to modern Baba Nyonya from Kuala Lumpur and Malacca.

Beside that, in depth interviews have been conducted with the deputy president of The Peranakan Association of Malacca, Datuk H.S.Yeo, and the secretary of The Peranakan Baba Nyonya Association of Kuala Lumpur and Selangor, Baba Cedric, and Assistant secretary of the association, Baba Teh Beng Boon. Throughout the interview, they have provided information concerning the current and future of Peranakan culture.

\section{The Origin of Constructing Baba Nyonya Identity}

In the late $15^{\text {th }}$ and $16^{\text {th }}$ century, Chinese traders arrived at the center of Malay Peninsula which is Malacca. Malacca is the original center of Baba Nyonya culture. Most of Chinese traders were from Hokkien. When Chinese traders came to Malacca, they did not bring their womenfolk; therefore, intermarriage with Malay women took place. Baba Nyonya culture is blend of Malay indigenous culture and the traditional Chinese culture. The term Baba shows male, and the term Nyonya shows female. It is not clear when Baba identity first developed; however, there are four important aspects to know how Baba Nyonya constructed their identity.

First of all, language is the most important aspect to know identity because it is a symbol of ethnic identity. Chinese Baba speak Baba Malay which contains Hokkien loanwords, standard Malay and Melaka Malay ${ }^{1}$. Baba Malay was developed thorough influence of Chinese culture. Once Baba adopted Malay, it enabled Baba to have interests on Malay literature, music and songs. Baba Malay is mixture of Hokkien, Malay and Malacca Malay; therefore, it helps Baba not only maintain their identity as Chinese, but also enable them to develop their interest in Malay culture. Moreover, Baba Malay developed Nyonya's interest in Chinese culture. Baba Malay was spoken as mother tongue in Malacca. Even though Baba Malay has played important role to construct identity, marriage with non-Baba Chinese has lead to live away from the Baba Nyonya society, and it tends to lose their identity as Baba Nyonya. It is because their children learn one of Chinese and lose their interests on Baba Malay. Therefore, although Baba Malay constructed Baba Nyonya identity, through marriage with non-Baba Malay, Baba Nyonya are losing their identity.

Secondly, religion is important to construct Baba Nyonya identity. The religion of the Baba Nyonya is the traditional Chinese folk religion. This Chinese religion is a polytheistic religious system which has a hierarchy of deities, ancestors and spirits, and ancestors worship was precious event for Baba Nyonya. The ancestors worship has been simplified, but Baba Nyonya still think that ancestor worship is crucial part of their life. Also, religion played role to draw boundary marker between Baba Nyonya and the Malays because the Malays are Muslim and the Baba Nyonya believed Chinese folk religion. Therefore, the religious difference made Baba Nyonya recognize them as Baba Nyonya which is different from Malays.

The third point is the Baba kinship system. The Baba kinship system is a transformation of the Hokkiem system, so that most of the kin terms are from Hokkien loanwords. It is necessary for Baba Nyonya to maintain Chinese terms to be able to name kinship relations. Also, there are distinctions in accordance with generation, sex and relative seniority. The Baba uses the patrilineal descent principle; therefore, surnames are from father's side. The influence the Baba kinship is that in Malay system, there is no distinction between the father's side and the mother's side, but in Baba system, there is a distinction between the father's side and the mother's side. Therefore, a distinction between the father's side and the mother's side made the relationship clear among Baba Nyonya society.

The last point is culture. The dresses such as sarong and kebaya were influenced by Malay culture, and color combination in special occasion is guided by Chinese culture. The shape of the clothes are from Malay culture, and the colors are from Chinese culture.In the case of cuisine, Peranakan food is influenced by not only Chinese and Malay cuisine, 
but also Indonesian, Thai, Indian, Dutch, Portuguese and English cuisines. The feature of Nyonya food is spicy and piquant flavors. Baba Nyonya eat food with fingers, like Malays do. Also, they use forks and knives, but not chopsticks. Baba Nyonya use chopsticks in the case of celebrations and festivals. Therefore, not only Chinese and Malay, but also western countries influenced Nyonya food and the way Baba Nyonya eat. The next point is architecture. Architecture is also influenced by both Chinese and Malay culture. For instance, the houses were built by either woods or stones. The material wood is the influence of Malay and the material stone is the influence of China. Also, the design of the house depended on fengshui which is from China. Therefore, Baba Nyonya culture has both Malay and Chinese elements, and these elements construct their identity as both Chinese and Malay.

In conclusion, there are four elements which construct the identity of Baba Nyonya which is language, religion, kinship and culture. The most important element is language which is Baba Malay because language can create their own community and give identity as Baba Nyonya. However, Baba Nyonya culture has been disappearing. The next part is constructing identity of modern Baba Nyonya.

\section{The Factors of Disappearance of Baba Nyonya Identity}

The Baba Nyonya identity has been disappeared, and there are five factors which have led to decline of Baba Nyonya identity in terms of geographical dispersion, immigration of Chinese, modernization, Wars and religions.

First of all, geographical dispersion of Baba Nyonya has led to decline of Baba Nyonya. Baba Nyonya used to live in Malacca, and kept their culture. However, Baba Nyonyas have scattered among Malaysia and the Southeast Asia. Therefore, Baba Nyonya have been socialized with other groups, and it made difficult for them to maintain their identity as Baba Nyonya.

The second factor is Chinese immigrants. In the late $19^{\text {th }}$ century, many Chinese migrants came to Malaysia, and due to the migrants from China, the Baba Nyonya disintegration took place. Also, intermarriage between Strait Chinese and non-Strait Chinese has diluted Nyonya culture because Babas marry non-Nyonyas, but Chinese. Therefore, Nyonya culture has been declined.

The third factor is modernization. Under modernization, family ties of Baba Nyonya became weak. At the peak of Peranakan culture, three generations stayed together in the same house, and language was transmitted from generation to generation. However, due to modernization, many Baba Nyonya did not practice customs and rituals. Also, Baba language was not transmitted because some Baba Nyonya families send their children to Mandarin schools and there was a pressure of English. Moreover, with modernization, the role of Nyonyas has been changed, and the culture has also been declined. In the past, Nyonya was taught to be good wife and mother, and the important things for Nyonyas was cooking and sewing. Therefore, they received little education. On the other hand, while Britain colonized Malaysia, many Nyonyas had education in English, so Nyonyas became free from constrained life. Also, modern Nyonyas do not know how to cook Nyonya food. Moreover, they do not use Baba Language to their children, so Baba Language has been disappearing. In some Baba Nyonya families, children learn Baba language not from their parents, but from their grandparents. Therefore, once their parents pass away, modern Baba Nyonya do not have opportunity to speak Baba language.

The fourth factor is World War II and Japanese invasion of Malacca. Due to World War II and Japanese invasion, many Baba Nyonya lost their properties and wealth, and their life style has been changed profoundly.

The last factor is religions. In the past, Chinese could marry Malays without converting to Islam. However, in the present, Chinese who get marry Malays need to convert to Islam, so they do not have a sense of belonging to Malay culture. Also, Babas think they are different from Chinese because their culture is influenced by Malay culture. Therefore, the religion separated Baba and Nyonya from Malay culture, and they aligned with Chinese community.

\section{The Future of Baba Nyonya Culture}

Our culture is not disappearing but evolving. The secretary of The Peranakan Baba Nyonya Association of Kuala Lumpur and Selangor said when we interviewed. There is no denying that the culture of Baba Nyonya seems marginalized by mainstreaming culture in Malaysia and western culture. Most respondent show that English is the 
languages which most common used and regarded as most freely express themselves.

However, both the interview and questionnaire demonstrate that the core of the culture-ancestor worship still is practiced by the descendant of Baba Nyonya. According to the deputy president of The Peranakan Association of Malacca, Datuk H.S.Yeo, even though many practice to worship ancestor have been simplified, but no matter what religion the Baba Nyonya embrace, they still go to temples to offer fruits and other gift to show their worship to ancestors once the important Chinese festivals such as Tomb-sweeping Day and Spring festival. Before, Baba Nyonya practice ancestor worship in home by enshrining ancestral tablets. Baba Nyonya who live in metropolis may not have conditions to follow the tradition, but they find a alternative way to carry on the ancestor worship. In this regard, we can say that the young modern Baba Nyonya do evolve their culture rather than abandon it.

Filial piety is another important value in Baba Nyonya culture. Though many Peranakan do not speak Baba Malay anymore, but the way they address their family member still use the exact word in Baba Malay. Also to marry another Peranakan still is regarded as preference. The bottom line is their companion will respect the culture and tradition of Peranakan. There are many cases that the non Peranakan especially Malay Chinese get chance to learn how to cook Nyoya cuisine and know the culture of Peranakan. In Kuala Lumpur, there are at least 20 Nyonya cuisine restaurants. These restaurants also played an important role to ensure the Peranakan culture are not disappearing.

Babas and Nyonyas do not live together as a community anymore, but many Pperanakan have great interest to promote the Peranakan way of life. The strong willing makes Peranakan in Malaysia especially Malacca, Penang and Kuala Lumpur and Selangor region as well as in Singapore and Thailand set up Peranakan association. What's more, these associations are able to form a network that link the Baba Nyonya in different places together by regular meetings and occasional functions, as well as the annual Chinese New Year get-together. The association does not only provide a platform to Peranakan to get together and promote their culture but also open a window to non-Peranakan to get to know the unique culture of Baba Nyonya by providing them membership in association. Taking the Peranakan Baba Nyonya Association of Kuala Lumpur and Selangor for example, though the association just set up for one and half years. It shows great dynamics in promoting Peranakan culture. There are 80 members in the association. According to the secretary, the association is going to provide classes in Baba Malay, cooking, making beading shoes as well as Peranakan art such as singing and dancing. They also hold programs such as Peranakan culture show and so on. The association address the Baba Malay by using it as communication language through meeting and email. To many members, joined the activities hold by association is a good chance for them to practice their Baba Malay.

\section{Conclusion}

The identity of Baba Nyonya was first constructed by mixture of two cultures through intermarriage. The mixture of the cultures happens in the era when has actually strengthened the existence of the culture and make it prosperous. As time and civil development goes by, it makes changes on the culture. Baba Nyonya is not disappearing but evolving into another stage with further mixture of other cultures. The original identity will not just disappeared in the air because they are recorded in the history and the modern Baba Nyonya will create a new page of their history. As it happens in every culture, no identity will be persisting as the same forever but it will be changing from time to time. It has not been forgotten but it has transform into the new phrase of identity.

\section{References}

1. Brubaker, R.; Cooper, F. (2000). "Beyond 'Identity"'. Theory and Society 29: 5.

2. T. Chee-Beng. (1988). Structure and change: Cultural identity of the Baba of Mekeka. Retrieved February 23, 2010, from http://www.kitlv-journals.nl

3. Lee Su Kim. (2008). The Peranakan Baba Nyonya Culture: Resurgence or Disappearance? Retrieved February 23, 2010, from http://pkukmweb.ukm.my

4. Lisa Lim \& Salikoko S. Mufwene. (2005). The sociolinguistic history of the Peranakans. Retrieved February 23, 2010, from http://www.hku.hk/linguist/sta/uansaldo/papers/AnsaldoLim\&Mufwene.pdf 